\title{
Polarity: The theology of anti-Judaism in Ephrem the Syrian's hymns on Easter
}

\author{
PJ Botha \\ University of Pretoria
}

\begin{abstract}
Polarity: The theology of anti-Judaism in Ephrem the Syrian's hymns on Easter
\end{abstract}

In this paper, the polarity Jews :: Christians in the hymns on Easter of the fourth-century Syrian theologian Ephrem is investigated. This polarity is found to be polemical against the Jews. But since polarity is a constant feature in the work of Ephrem which serves to communicate his theological frame of mind, the question is asked whether anti-Judaism does not also serve to convey theological ideas. An attempt is made to demonstrate that anti-Judaism indeed had a theological function for Ephrem: Anti-Judaism seems to have been an aspect of Christian self-definition. It was also a way of expressing the concepts of theological balance and reciprocity.

\section{INTRODUCIION}

One of the most noteworthy theologians of the patristic era is also one of the most neglected. Ephrem the Syrian (c 306-373) was born in Nisibis and became deacon in about 338. After the Persian occupation of Nisibis in 363 , he made his way to Edessa which then lay just inside the Byzantine frontier. He declined the honour of a high clerical position, but served the community of believers in various ways. He acted as spokesman for his bishop, conducted the choir and taught theology at the famous 'School of the Persians' in Edessa (El-Khoury 1976: 16-20). Shortly before

\footnotetext{
- Finansiële ondersteuning van die Raad vir Gecsteswetenskaplike Navorsing in dic voorbereiding van hierdie artikel word hicrmec erken. Dic menings wat in hierdie artikel uitgespreck word en dic gevolgtrekkings waartoc gekom word, is dié van dic outcur cn nic noodwcndig dié van dic RGN nic.
} 
his death in 373 , he took it upon himself to organise relief for the poor during a famine (Brock 1985: 18). But Ephrem's one outstanding contribution to the Syrian church was a treasure of liturgical hymns which seemed to flow from his pen in an incessant stream. Such was his capacity for writing poetry that he was appreciatively referred to as 'the prophet of the Syrians', 'the sun of the Syrians', 'the pillar of the church' and 'the lyre of the Holy Spirit' (Bardenhewer 1962: 342).

Ephrem's literary rhetoric bears resemblance to that of the Bible in many respects. The skilful expression of contrast and paradox through the use of antithetic word-pairs and phrases is a common feature in the work of the two outstanding Syrian theologians of the fourth century, Aphrahat and Ephrem (cf Martikainen 1981: 11-12). As a result of Ephrem's preference for poetry as a literary medium, in contrast to the sole use of prose in Aphrahat's extant work, the polar structure of Ephrem's hymns seems all the more conspicuous. One such polarity which is common to both Syrians, but which seems to abound especially in the hymns of Ephrem, is that of the antithetic word-pair 'people :: peoples'. This opposition is similar to the contrast between 'people' and 'gentiles' in the Old Testament, but the (church from the) 'peoples' is endowed by Ephrem with a positive connotation, while the word 'people' is used as a denigratory term for the Jews.

Ephrem's hymns on Easter, namely the collections on the unleavened bread ( $D e$ Azymis), on the crucifixion (De Crucifixione) and on the resurrection ( $D e$ Resurrectione) provide ample opportunity for the exploitation of the polarity between Jews ('the people') and Christians ('the peoples'). Reading these hymns, one becomes aware of the skill of Ephrem to put polarity to effective use in polemics. The contraposition of comparable but opposite elements brings about a semantic and semiotic tension which serves to enhance the power of his arguments (cf Botha 1988: 581-595).

Another aspect of this polarity which deserves our attention, however, is its theological dimension. Polarity seems to be the outstanding feature of Ephrem's hymns and characterises his approach to theology. In contrast to the Greek theological tradition which sought to set öpot, boundaries, by way of theological definitions, Ephrem was of the opinion that to try to 'define' God was a sacrilegious endeavour (Brock 1985: 10). His alternative approach was by way of poetry and through the use of paradox and symbolism which fitted into the framework of poetry as his favourite medium. In this way, his theology so to speak did not seek the centre of the circle (the aspect under investigation), but located opposite points of the circle by way of paradox and thereby described the circumference of the circle in a dynamic rather than a static way (Brock 1985: 11). 
The question that concerns us here is the function of the polarity Jews :: Christians. Ephrem's hymns is fiercely anti-Judaistic and the opposition between Jews and Christians in his hymns on Easter was certainly meant to be polemical. But how does this polarity relate to Ephrem's theology? I propose to show that the polarity Jews :: Christians in Ephrem's hymns should be related to his theology. Anti-Judaism itself had a theological function in forming a foil for Christian selfdefinition. Moreover, the polarity between Judaism and Christianity had the function of placing emphasis on the point of balance between the two systems: the Christ-event.

\section{THE POLARITY PEOPLE :: PEOPLES}

\subsection{The opposing zeal of Jews and Christians}

In Ephrem's hymns on Easter (De Azymis II 13-14), the Jewish people and the Christian church are counterbalanced via a set of antitheses:

Hope came for the people; the people cut off its hope and threw it to the peoples, and they were without hope.

The peoples hastily put on the hope that they had taken off.

The hope which the prophets longed to see, who would not be astonished that the mad ones, because they saw it (him), hastened to despise him as to why he had come in their days.

Hope is metaphorically presented as clothing which is 'cut off, 'taken off', 'thrown' away and 'put on'. But it is also a metaphor for the messiah, since 'hope' is personified in the next strophe:

For this reason he came in their days: that he would have mercy if they would accept him, and if they would reject him, that they should know how mad they were to despise their light.

The polarity formed by the Jews and the Christians are thus defined by two sets of antitheses: 
The people

1. Hastened to despise Christ

2. 'Took off' hope
The peoples

1. Hastened to put on Christ (cf Rm 13: 14).

2. 'Put on' hope

The word for 'to hasten' is used to stress the similar but opposite zeal in relation to Christ:

People $\rightarrow$ negative zeal $\rightarrow$ Christ $\leftarrow$ positive zeal $\leftarrow$ Peoples

\subsection{Rejection and election}

In reaction to the negative and positive zeal shown respectively by the Jews and the Christians, which leads to the Jews rejecting their messiah and the Christians accepting him, God reacts by rejecting the Jews and electing the Gentiles:

Because they put him between the robbers in their anger, they hinted on themselves. For the one on the left is their symbol. In him they were rejected, for he chose the peoples which hastened to take refuge in his crucifixion, like the (other) robber ... (De Crucifixione V 7).

This suggests the following polarity:

People $\leftarrow$ rejected $\&$ Christ $\rightarrow$ chosen $\rightarrow$ Peoples

Rejection of the Jews by God had, however, important consequences. It meant, for instance, that they would be punished for their ingratitude (cf De Azymis II 16):

It is difficult for an unjust person to realise that he is unjust.

Since he does not perceive his evilness while he does not experience

it, he will learn from his (own) unjustness the taste of his evilness.

One aspect of the punishment of the Jews was their being dispersed. Their dispersion, however, stands in relation to the gathering of the church ( $D e$ Crucifixione IV 13):

The people was dispersed so that the peoples could be gathered, the sanctuary was pulled down; our sanctuary is erected. 
This dispersion of the Jews serves to prove that the imminent judgement (cf $D e$ ' Azymis XIII 27, De Crucifixione V 8) has already begun for the Jews. The people is without hope (De Azymis Il 13) and the peoples despise them (De Crucifixione V 5):

Since they despised the circumcised while he was crucified in their country, the nation of the peoples despises the rejected one.

In contrast to them, the peoples are baptised, washed, cleansed and renewed ( $D e$ Crucifixione IV 16). The following polarity can be deduced from the abovementioned antitheses:

$$
\text { People } \leftarrow \text { punished }<\text { Christ } \rightarrow \text { redeemed } \rightarrow \text { Peoples }
$$

\subsection{The polarity particularism :: universalism}

As a result of all nations being included in the church, the people and the peoples are also contrasted in terms of particularism and universality. The sacrificial system of the Jews was closely linked to the sanctuary in Jerusalem. In contrast, holy communion can be practiced everywhere (De Azymis XXI 22, 24-25):

In Jerusalem alone it was permitted to perform (the rites of) feast and sacrifice....

In stead of the sacrifice of all kinds of animals that was made in Jerusalem alone

the living body is now being sacrificed in our days, the living sacrifice, over the whole earth.

Thus:

People $\rightarrow$ centralised $\rightarrow$ cult $\leftarrow$ universal $\leftarrow$ Peoples

2.4 The polarity temporality :: truth

The relationship between the religion of the Jews and that of the Christians is of a symbolic nature according to Ephrem. This applies especially to the material being treated in hymns on Easter:

On this feast, the blood of the true lamb was mixed within the disciples.

On this feast, the temporal lamb gave temporal salvation to that people (De Azymis V 16,17). 
This results in the following polarity:

People $\rightarrow$ temporal $\rightarrow$ salvation $\leftarrow$ true $\leftrightarrow$ Peoples

2.5 The polarity symbol :: fulfilment

The exegetical tradition which Ephrem follows, also serves to strengthen the notion of polarity between the Jews and Christians:

Praise to him who has saved the peoples with his blood in stead of the symbol that had saved only that people (De Azymis XXI refrain).

On this feast, the temporary lamb gave that people temporany salvation. On this feast, deception fled through the true lamb that taught truth. That lamb of symbols was substituted since fulfilment came and fulfilled the symbols.

The tnuth of the true lamb does not terminate - what could be greater than it so that it (in tum) would be substitured (De Azymis V 17-20)?

The 'symbol' thus becomes a type of an antitype in the Christian dispensation:

People - symbol $\rightarrow$ Passover $\leftarrow$ fulfilment $\leftarrow$ Peoples

The people of the old dispensation was made obsolete together with their symbols (De Azymis XIX refrain):

Praise to Christ, through whose body the unleavened bread of the people was abolished together with the people.

\section{THE THEOLOGICAL DIMENSION OF: POI ARITY}

The above investigation has established that the people and the peoples are contrasted through the use of antitheses and antithetic phrases on a literary level. The two Syriac words for 'people' and 'peoples' are similar in respect of sound

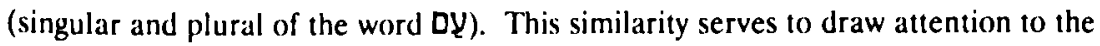
different connotations and the polar quality of pronouncements in which the singular and plural of the word 'people' are used. While they are morphologically and paradigmatically related, they are syntagmatic opposites. 
From these examples it has also become clear that Ephrem makes no distinction between the Israelites of the Old Testament period, the Jews of Jesus' time, or his own contemporaries. In one hymn, namely De Azymis XVIII, the word for 'people' has the following denotations:

1. The Israelites at the institution of the feast of Passover (refrain);

2. The Jews that pierced Christ with a spear (sic) (strophe 4);

3. The people as referred to in Deuteronomy 32: 15 (strophe 5);

4. The people as referred to in Isaiah 1:3 (strophe 7); and

5. The Jewish contemporaries of Ephrem (strophe 9 and 12).

By means of the historical link between the Jewish feast of Passover and the Christian Easter, Ephrem establishes the notion of a history of confrontation. According to this surmise, the Israelites and the Jews are one and the same people since they are not only genealogically related, but also possessed by the same ideological disposition of antagonism against God. Antagonism between God and Israel (cf De Resurrectione III 2 and 3) results in antagonism between the Jews and Christ (cf De Resurrectione III 4 and 5; De Azymis II 10). This develops into antagonism between Jews and Christians (cf De Azymis XVIII 6,7,8-10, 11, 16; De Azymis XIX 5,22 and 24).

The Old Testament metaphor of a marriage between God and Israel is developed into an allegorical history:

(i) Israel is the bride of the king (God) that fornicates (the worship of the golden calf) in the month Nisan, just after the wedding. The king then rejects her as bride, but engages her daughter (the Jews) to his son (Christ) ( $D c$ Resurrectione III 2 and 3).

(ii) The Jews (as bride of the messiah) rejects the bridegroom. They kill the prince in the month of Nisan. Consequently, God rejects them. This results in the wedding of the 'peoples' with Christ (De Resurrectione III 4 and 5, De Azymis II 10).

(iii) The polarity is continued through the antagonism of the Jews against Christians. The guilt of the death of Christ clings to them (Mt 27: 25 is used as proof of this). Furthermore, they want to kill the faith of the followers of Christ (De Azymis XVIII 6,7,8-10,11,16; XIX 5,22 and 24). This polarisation also culminates in Nisan. 
The polarity can be illustrated by the following diagram:

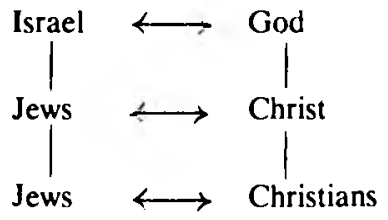

As a result of the solidarity between Israel and the Jews, there is also a solidarity between the elements of the opposite pole: God, Christ and the church are united through the continual antagonism of the Jews.

The polarity between Jews and Christians should thus not be viewed in isolation from the polarity between God and Israel (as expressed by Old Testament prophets) and the polarity between 'the Jews' and Christ (as expressed by the Gospels). Antagonism of Jews against Christians shows them only to be true to their nature of apostasy; on the other hand, animosity of Christians against Jews is propagated as a religious duty, since this establishes solidarity with Christ and therefore with God. It can therefore be said that anti-Judaism in Ephrem's day had a theological dimension.

Another aspect of the polarity between Jews and Christians relates to the theological concept of reciprocity. The rejection of Christ by the Jews is balanced by the rejection of the Jews by God. The contempt of the Jewish contemporaries of Jesus for their messiah is balanced with contempt for the Jews by all nations. Reciprocal action by God and by Christians seems to establish a doctrine of retribution. This in turn projects the concept of order in God's universe and in his actions with man.

Religious history is also presented as a polar structure. Every aspect of Israelite religion has a superseding parallel in Christianity and the two dispensations are finely balanced in the elements of the feast of Passover. It is as a result of this view of Christianity as a mirror image of Judaism, in which the reversal of attitude is particularly stressed, that reflection on the feast of Passover, and especially the crucifixion of Christ, becomes essentially anti-Judaistic.

\section{ANTI-JUDAISM AND THEOI OGY}

To my mind, Christian theology was characterised since its inception by a polar structure. With 'inception', the Jewish phase of Christianity is of course not taken into account, for it is with the period of growth of the gentile church that the 
opposition between 'law' and 'grace' developed. This opposition is nevertheless already present in the New Testament where it may be detected in the form of polar word-pairs and antitheses. The Christian church understood itself to be God's true Israel ( $\mathrm{Gl}$ 6: 16) as opposed to the empirical people which made up Israel in the flesh (I Cor 10: 18). This posed a hermeneutical problem, since no historical development leads from Israel to Judaism and from there directly to Christianity (Gunneweg 1978: 20). The hermeneutical key that Christianity found in treating Hebrew scripture as prediction and prophecy and promise (cf Gunneweg 1978: 21), strengthened the polar structure of its theological reflection.

The church felt that it could establish its own legitimacy only by claiming for itself the heritage of ancient Israel and denying it to the Jews (Gaston 1986b: 164). The anti-Judaism of the New Testament itself was of a theological nature. Matthean anti-Judaism, for instance, seems to have served primarily as a tool in the struggle for identity of the Matthean church (Pryzybylski 1986: 199). Likewise, the anti-Judaism of Luke-Acts is aimed at overcoming the (theological) problem of the legitimacy of the Christian community after the fall of Jerusalem and the shift of the church to an almost completely Gentile Christian movement (Gaston 1986a: 139).

Christian theology was devised as a theology of opposition: reality in opposition to typology; truth in opposition to symbols; fulfilment in opposition to prediction; the 'letter' which kills in opposition to the spirit which brings to life (II Cor 3: 14). Patristic theology carried on in the same vein. The rejection and acceptance of Christ; the rejection of the Jews and acceptance of gentiles by God; the judgement on the Jews and the salvation of the church; the centralised cult and the universality of the church; the cult of symbols and the religion of truth; and Old Testament types and Christian fulfilment - all form part of a literary tradition that remained fairly constant during the period from the second to the sixth century of the Christian era and to which writers before and after Constantine and from the Syriac, Greek and Latin branches of the church attest (cf Ruether 1978: 118). According to Ruether (1978: 118), the two most important aspects of this tradition were (a) the rejection of the Jews and the election of the gentiles and (b) the view that the Jewish law, cult and interpretation of scripture were inferior and were fulfilled. The polarisation of Judaism and Christianity it implied, is evident.

The polarity between Jews and Christians in the hymns of Ephrem should thus be seen in its relation to a literary and theological tradition. Although his polemics were related to the socio-political context at the time of their origin, it must be remembered that early Christianity saw itself as the theological opposite of Judaism, and this gave rise to a polar structure which was anti-Judaistic but not necessarily anti-Jewish. As is the case with Melito (cf Wilson 1986: 95), certain anti-Jewish 
themes in Ephrem should be seen as the reverse side of an attempt to articulate a definition of Christianity.

\section{CONCLUSION}

In relation to Judaism, Christianity may be viewed as a new theological paradigm. Criticism of its predecessor is often the most conspicuous feature of a new dogmatic paradigm, and the polarity between Judaism and Christianity can therefore be seen as an existential necessity in early Christian thinking. This polar context which formed the cradle for Christian theology was continued through the development of theology itself, thereby creating a hermeneutical circle. Anti-Judaism in the hymns of the church father Ephrem was, inter alia, a way of claiming legitimacy for Christianity. According to Gaston (1986b: 164), diverse elements of Christianity could be rallied under the common cause of protection against the dangers of Judaism. Ruether's conclusion (Ruether 1974: 81) that anti-Judaism in the church fathers was an intrinsic necessity of Christian self-affirmation which presented an answer to specific theological problems the early church had to cope with, thus seems substantiated from a study of Ephrem's hymns on Easter.

Finally, it should be remembered that texts have a life of their own once they had been called into existence. Anti-Judaistic texts from the patristic era had - quite apart from the existential necessity which might have prompted their origin - a profound influence on generations of Christians. From theological opposition and criticism of a system in order to establish self-understanding, anti-Judaism and retribution developed into a dogma of the church. The present identification of the existential need for anti-Judaistic polemics should not be taken as a condonation of the actions that eventually resulted from it. On the contrary, it should help to uncover a religious and social prejudice that became antiquated already at the time of its inception.

\section{Works cited}

BARDENHEWER, O 1962. Geschichte der altkirchlichen Literatur, 4. Band: Das fünfte Jahrhundert mit Einschluss der syrischen Literatur des vienen Jahrhunderts. Darmstadt: Wissenschaftliche Buchgesellschaft.

BECK, E (Hrsg) 1964. Des heiligen Ephraem des Syrers Paschahymnen (De Azymis, De Crucifixione, De Resurrectione). Corpus Scriptorum Christianorum Orientalium vol 248, Scriptores Syri, tome 108. Louvain: CSCO. 
BOTHA, PJ 1988. Antithesis and argument in the hymns of Ephrem the Syrian. HTS 44, 581-595.

BROCK, SP 1985. The luminous eye: The spiritual world vision of St Ephrem. Placid lectures, Centre for Indian and Inter-religious studies. Rome: CIIS.

EL-KHOURY, N 1976. Die Interpretation der Welt bei Ephraem der Syrer. Mainz: Grünwald. (Tübinger Theologische Studien 6.)

GASTON, L 1986a. Anti-Judaism and the passion narrative in Luke and Acts, in Richardson, P \& Granskou, D (eds), Anti-Judaism in early Christianity, Vol 1: Paul and the Gospels, 127-154. Waterloo: Wilfrid Laurier University Press. (Studies in Christianity and Judaism, no 2.)

GASTON, L 1986b. Retrospect, in Wilson, S G (ed), Anti-Judaism in earty Christianity, Vol 2: Separation and polemic, 163-174. Waterloo: Wilfrid Laurier University Press. (Studies in Christianity and Judaism, no 2.)

GUNNEWEG, AHJ 1978. Understanding the Old Testament. London: SCM.

MARTIKAINEN, J 1981. Gerechtigkeit und Güte Gottes: Studien zur Theologie von Ephraem dem Syrer und Philoxenos von Mabbug. Wiesbaden: Harrassowitz. (Göttinger Orientforschungen, 1. Reihe: Syriaca, Band 20.)

PRYZYBYLSKI, B 1986. The setting of Matthean anti-Judaism, in Richardson, P \& Granskou, D (eds), Anti-Judaism in early Christianity, Vol 1: Paul and the Gospels, 181-200. Waterloo: Wilfrid Laurier University Press. (Studies in Christianity and Judaism, no 2.)

RUETHER, RR 1974. Faith and fratricide: The theological roots of anti-Semitism. New York: Seabury.

RUETHER, RR 1978. Nächstenliebe und Brudermord: Die theologischen Wurzeln des Antisemithismus. München: Kaiser.

WILSON, SG 1986. Melito and Israel, in Wilson, S G (ed), Anti-Judaism in early Christianity, Vol 2: Separation and polemic, 81-102. Waterloo: Wilfrid Laurier University Press. (Studies in Christianity and Judaism, no 2.) 